\title{
Hubungan Power Tungkai dengan Tendangan Mawashi Geri dan Ushiro Mawashi-Geri pada Cabang Olahraga Karate
}

\section{Sari Yurika Kusmirantini}

Program Studi Ilmu Keolahragaan, Departemen Pendidikan Kesehatan dan Rekreasi, Fakultas Pendidikan Olahraga dan Kesehatan, Universitas Pendidikan Indonesia, Indonesia

Kata Kunci:
karate, tendangan, mawashi geri,
ushiro mawashi-geri, power
tungkai

\begin{abstract}
Abstrak
Tujuan dari penelitian ini adalah untuk mengetahui hubungan antara power tungkai dengan hasil tendangan mawashi geri dan ushiro mawashigeri pada cabang olahraga karate. Metode penelitian yang digunakan adalah metode kuantitatif dengan studi korelasional. Sampel yang digunakan dalam penelitian ini adalah mahasiswa UKM Karate UPI sebanyak 10 orang yang telah mengikuti berbagai event Nasional. Instrumen yang digunakan dalam penelitian ini adalah digital vertical jump dan nuboya maeter dengan validitas sebesar 0,70 dan reabilitas 0,72 .. Hasil analisis data dari penelitian menunjukan bahwa terdapat hubungan antara power tungkai dengan hasil tendangan mawashi geri dan ushiro mawashigeri pada cabang olahraga karate. Hal ini terlihat dari nilai hasil tendangan yaitu 0,815 dengan signifikansi $0,004<0,05$ dan 0,782 dengan signifikansi $0,008<0,05$. hal ini menggambarkan bahwa power tungkai merupakan faktor penting untuk menghasilkan tendangan mawashi geri dan ushiro mawashi-geri. Dengan kata lain semakin besar power tungkai maka semakin baik upaya menendang dari sisi kekuatan dan kecepatan.
\end{abstract}

\begin{abstract}
The purpose of this study was to determine the relationship between leg power and kick results from Mawashi Geri and Ushiro Mawashi-Geri in the karate sport. The research method used is a quantitative method with correlational studies. The sample used in this study was 10 students of UPI Karate UKM who had participated in various National events. The instruments used in this study were digital vertical jump and nuboya maeter with validity of 0.70 and reliability of 0.72 . The results of data analysis showed that there was a relationship between leg power and results of kicks of Mawashi Geri and Ushiro Mawashi-Geri on branches karate sports. This can be seen from the kick value that is 0.815 with a significance of $0.004<0.05$ and 0.782 with a significance of $0.008<0.05$. this illustrates that leg power is an important factor for producing Gaw and Mawashi Geri Khiashi kicks. In other words, the greater the leg power, the better the kicking effort is in terms of strength and speed.
\end{abstract}

(C) 2019 Universitas Pendidikan Indonesia

Alamat korespondensi: eISSN: 2549-6360

Gedung FPOK Lantai 2 FPOK UPI

Universitas Pendidikan Indonesia, J1. Dr. Setiabudhi No. 299 Bandung

E-mail: Yukarikha66@gmail.com 


\section{PENDAHULUAN}

Berdasarkan pengalaman peneliti dan pengamatan-pengamatan pada setiap pertandingan karate khususnya nomor kumite teknik-teknik yang sering dipakai atlet, selain teknik pukulan ternyata teknik tendangan juga banyak digunakan atlet terutama untuk mengejar poin karena teknik tendangan memiliki poin tertinggi yaitu ippon (tiga). Selain dapat menghasilkan poin yang besar, serangan tendangan menghasilkan kekuatan yang lebih besar dari serangan pukulan (Nakayama, 1966, hlm. 136). Namun teknik serangan tendangan memiliki beberapa kelemahan diantaranya sulit dilakukan, beresiko, akan mudah ditangkis atau diserang balik oleh lawan.

Teknik tendangan merupakan teknik yang dilakukan oleh tungkai yang terpusat pada kaki, menurut Notosoejitno (1997, hlm. 68) mengatakan "Serangan tendangan adalah suatu serangan yang langsung terarah pada lawan atau sasaran dengan menggunakan kaki yang dilakukan sesuai teknik dasar". Teknik tendangan merupakan teknik yang istimewa dalam karate karena selain memiliki kekuatan yang lebih besar dari pada serangan pukulan, teknik tendangan lebih banyak variasinya dibandingkan dengan teknik serangan pukulan. Seperti halnya dalam penelitian Susanto (2004) menyatakan dalam setiap pertandingan kumite para atlet rata-rata lebih sering melakukan serangan tendangan dengan presentase $69,23 \%$. Hal tersebut menjadi gambaran bahwa teknik serangan tendangan merupakan teknik yang banyak digunakan oleh para atlet kumite dalam setiap pertandingannya.

Kurang efektifnya power pada saat melakukan serangan tendangan membuat peneliti ingin mengkaji mengenai hubungan power tungkai terhadap hasil tendangan mawashi geri dan ushiro mawashi-geri pada cabang olahraga karate. Penulis berharap hasil dari penelitian ini dapat digunakan sebagai referensi untuk para atlet karate. Karena dalam pertandingan kumite menendang dengan kuat dan tepat sasaran agar lawan sulit mengantisipasi tendangan dan mendapat poin sangat diperlukan.

\section{METODE}

Metode yang digunakan dalam penelitian ini adalah dengan menggunakan metode deskriptif kuantitatif korelasi.

Penelitian ini menggunakan teknik sampling purposive, yaitu teknik penentuan sampel dengan pertimbangan tertentu (Sugiono, 2013, hlm. 85), sehingga pertimbangan sampel yang dipilih oleh peneliti adalah anggota aktif UKM Karate UPI yang sering mengikuti beberapa event pertandingan. Maka peneliti mengambil sampel sebanyak 10 orang yang mengikuti kejuaraan nasional karate antar perguruan tinggi pada bulan maret 2017. Instrument yang digunakan pada penelitian ini adalah dengan menggunakan alat digital vertikal jump dan nuboya meter. Adapun langkah-langkah dalam penelitian ini adalah : (1) Menetapkan populasi dan sampel penelitian, (2) Pengambilan dan pengumpulan data melalui tes dan pengukuran, (3) Pengolahan data dan menganalisis data, (4) Menetapkan kesimpulan

\section{HASIL DAN PEMBAHASAN}

Hasil penelitian menunjukan bahwa terdapat hubungan antara power tungkai dengan hasil tendangan mawashi geri dan ushiro mawashi-geri pada cabang olahraga karate. Hal ini menggambarkan bahwa power tungkai merupakan faktor penting untuk menghasilkan tendangan mawashi geri dan ushiro mawashi-geri.

Temuan lain dalam penelitian ini menunjukan bahwa power tungkai memberikan kontribusi yang lebih besar terhadap hasil tendangan mawashi geri dibandingkan dengan hasil tendangan ushiro mawashi-geri dalam olahraga karate. Besarnya kontribusi power tungkai terhadap hasil tendangan mawashi geri disebabkan karena power tungkai merupakan faktor utama untuk menghasilkan dorongan ke arah sasaran. Maksudnya adalah power tungkai yang besar akan mampu melakukan tendangan yang kuat dan cepat. Hal ini sejalan dengan penelitian bahwa atlet yang mempunyai power tungkai yang baik akan menghasilkan tendangan yang baik pula. Penelitian mengenai power tungkai ini juga memberikan kontribusi yang besar terhadap hasil tendangan mawashi geri dan ushiro mawashi-geri, namun ada beberaapa faktor lain yang juga memberikan kontribusi terhadap hasil tendangan tersebut diantaranya keseimbangan dan fleksibilitas yang dimiliki 
oleh masing-masing atlet. Permasalahan ini perlu diteliti lebih lanjut agar faktor-faktor lain yang dapat mempengaruhi hasil tendangan mawashi geri dan ushiro mawashi-geri dapat teridentifikasi.

\section{KESIMPULAN}

Berdasarkan hasil pengolahan dan analisis data, maka kesimpulan dari hasil penelitian ini adalah sebagai berikut : (1) Terdapat hubungan antara power tungkai terhadap hasil tendangan mawashi geri pada cabang olahraga karate. (2) Terdapat hubungan antara power tungkai terhadap hasil tendangan ushiro mawashi-geri pada cabang olahraga karate

\section{DAFTAR PUSTAKA}

Nakayama (1980). Best Karate Comprehensive. Jakarta: P.T Indira.

(1997). Best Karate Fundamentals. Japan : Kodansha International Ltd.

World Karate Federation. (2010) Competition Rules Version 6.1 Madrid.

Notosoejitno (1997 dan 2001) Khazanah Bela Diri Pencak Silat. Jakarta :CV Infomedika.

Sugiyono. (2013) Metode Penelitian Pendidikan. Bandung: ALFABETA. 